any catholike preist doth unto his prince in catholike cuntreyes, or as ever any preist was faythfull to her grandfather of famous memory or to any her predicessors before his tyme. And so in most humble manner I take my leave this $14^{\text {th }}$ of Novemb. 1602

Your Honors to command.

\title{
Endorsement :
}

To the $\mathrm{R}^{\mathrm{t}}$ Honorable my very good Lord $\mathrm{y}^{\mathrm{e}}$ Lord Bishop of London.

\section{Letter from Anthony Heborne to Blackwell.}

Nov. 11, 1602.

To the R. R. Mr. George Blackwell archp̃st of England R. R.

The 30 of the last moneth I receyued lies from my bretheren the Appellants in Fremingham of their extreme distresses sustayned now for a long time, \& because they intreat my labour for some reliefe, I haue therefore thougt it meete to acquaint your R. $w^{t}$ their wants, who by $\mathrm{yo}^{\mathrm{r}}$ charitable hand to them \& $\mathrm{yo}^{\mathrm{r}}$ letters to others in their behalfe is well knowne to be best able to doe for them. It was my chance in June last to come to $\mathrm{y}^{\mathrm{t}}$ castle, at $\mathrm{w}^{\mathrm{ch}}$ time the sayd Appellants shewed me how that many moneths together, they had not receyved above the rate of $\mathrm{ij}^{\mathrm{s}} \mathrm{iiij}^{\mathrm{d}}$ by the week in common divident: and now they write, that they haue not receyved after the ráte of xxiijd by the weeke of the sayd common charitie for these three laste moneths next before their present letter, in $w^{\text {ch }}$ also they declare how they be furder tould $\mathrm{y}^{\mathrm{t}}$ they shall receyve yet lesse than they doe.

Yor R: knoweth that they be catholik priests suffering for the name of $o^{r}$ Lord Jesus ; \& of what necessaries for life, winter, \& their condition, they doe stand in neede. you likewise knowe that they haue noe liuings, but doe whollye rest for meate, drinke, 
cloth, fireing, housrome, \& other requisits to lyfe, upon the providence of God, to be mainteyned by the oblations of his people as others of their qualitie are; \& how that for this cause much almes hath ever beene given through the whole realme toward such charitable vses, \& as yor self haue written more these latter years then before, $\mathrm{w}^{\mathrm{ch}} \mathrm{I}$ take to come to yo ${ }^{\mathrm{r}}$ owne or yo assistants hands by reason of your office, \& to be delivered over againe, to the ordinarie distribution of everie place, to dispose there of both equally to all, \& in case of necessitie vnto every person as theire neede requireth, but as you see the distributor in that castle soe dispenseth the same, that some have in competent measure, \& others wante even for meere necessities. This difference in distribution you know must needs be either the sayd dispensers owne deed, or els proceed from the receyvers, or the almes-givers, or from some other interposed collectors or dealers in this busines, \& a cause must be thereof \& of the choyse thus made of priests, $\&$ difference so putt betwene persons. The givers of the almes be the catholiks dispersed generally through the whole realme; $\mathrm{y}^{\mathrm{e}}$ receyvors are taken to be $\mathrm{yo}^{\mathrm{r}} \mathrm{R}$ :, $\mathrm{yo}^{\mathrm{r}}$ assistants, \& happily also the fathers of the societie; the collectors \& others interposed, such as liketh the givers and you to vse; the imediate dispenser there at Fremingham is said to be fa. Coffin. Those in wante be priests, in number six, men for priestly cariage noe more subiecte to exceptions, than the rest there be, from whom they differ in nothing but in being Appellants to the courte of Rome upon the causes $\mathrm{y}^{\mathrm{t}}$ you know, in $\mathrm{w}^{\text {ch }}$ respect if the immediate dispenser there and others where soever, or the almes givers abroad or those through whose hande the sayd almes cometh, doe make the aforesayd difference \& restraynt of reliefe from them, \& $\mathrm{y}^{\mathrm{t}} \mathrm{yo}^{\mathrm{r}}$ charitie doo not allowe thereof, but doo hould the course repre[he]nsible, and meete to be amended; yo ${ }^{\mathrm{r}}$ letters for the contrarie 54, f. 240b. may soone redresse it; the $\mathrm{w}^{\text {ch }}$ letters $I$ doe earnestly besich for resolving of some that promissed to give them some releif, so .. . uld shew your letters that he might $[k]$ now what feare \& 
doubt in him of the contrarie this answere doth importe $\mathrm{yo}^{\mathrm{r}}$ wisdome can well perceyve, \& may thereby the better iudge and see. of what necessitie for those distressed priests the shewinge of yo $^{r}$ letters is ; not only to the immediate dispenser there, but also to many catholiks abroad that be slack towards their relief, happily vpon the aforesayd foare or doubt, conceyved either of themselves or by the teaching of others, it being verie appar[ent] that neither that slacknes can be whout some motives, nor . . . ${ }^{\text {a }}$ motives want their cause \& beginning. I have layd . . . thus before $\mathrm{yo}^{\mathrm{r}}$ eyes the necessities of my brethren and made the causes to appeare from whome the same must needs proceed, \& $w^{\text {thall }}$ the meanes wh[ere] by they may be helped, charitie \& their necessitie inforcing me so to do. you know yor office, \& the charge wherew ${ }^{t} h$ you stand burdened, \& can well foresee of what example to catholiks yo $^{r}$ charitie equally extended to them $w^{\text {th }}$ the rest there would be, what helpe yo ${ }^{r}$ letters may bring them; \& what hindrance of relief and increase of their wants $y 0^{\mathrm{r}}$ silence will procure : and I need not tell you how men will marke to see what you doe in this matter, \& by yo ${ }^{r}$ deed gather your minde, those at least who know I writte, \& will look to see your answere; therin to receyve satisfaction; $w^{\text {ch }}$ answere once again I besich to have, and that w $^{t} h$ yo $^{r}$ first convenience, least through wante thereof my indevours in this meane time taken for my bretheren be hindered, whose needes you see to be so great as they cannot suffer any long delays. this $11^{\text {th }}$ of November. 1602

yor R. most obedient

A. $\mathrm{H}$.

24. Letter from Blackwell in answer to Heborne. [Original.]

17 Nov. 1602.

Sir

I would have you not to be so vehement in a matter, wherein I am blamelesse. I have considered them of Framingham further - Edge of MS. torn off here.

VOL. II. 